\title{
Persepsi Generasi Y Terhadap Kerajinan Tangan Daerah
}

\author{
Hazmanan Pasaribu ${ }^{1)^{*}}$, Chali Rafi ${ }^{2)}$, Khairawati ${ }^{3)}$ \\ ${ }^{1)}$ Program Studi Manajemen Fakultas Ekonomi \& Bisnis Universitas Muhammadiyah Sumatera Utara \\ Jalan Kapten Muckhtar Basri No. 3 Medan, Sumut, Indonesia \\ *email: hazmananpasaribu@gmail.com \\ ${ }^{2,3)}$ Jurusan Manajemen Fakultas Ekonomi \& Bisnis Universitas Malikussaleh, Lhokseumawe, NAD \\ email : chalirafi@unimal.ac.id
}

\begin{abstract}
\begin{tabular}{c} 
Article Info \\
\hline Received: \\
13 September 2017 \\
Revised: \\
13 Oktober 2017 \\
Accepted: \\
29 Oktober 2017 \\
\hline
\end{tabular}
ABSTRAK

Perkembangan dunia usaha produk kerajinan tangan saat ini cukup berkembang pesat ditandai dengan semakin ketatnya persaingan produk kerajinan tangan antar daerah, untuk itu pengusaha kerajinan tangan Aceh harus menunjukkan daya saing yang tinggi terhadap produk daerah lain dengan cara melakukan strategi pemasaran yang baik. Generasi Y merupakan segmen pasar konsumen yang penting di masa depan karena peningkatan pertumbuhan generasi ini semakin pesat dan juga merupakan kelompok berpenghasilan tinggi. Sehingga generasi $\mathrm{Y}$ telah menarik perhatian beragam kelompok penelitian dalam berbagai disiplin ilmu. Tujuan penelitian ini adalah untuk mengidentifikasi persepsi generasi $\mathrm{Y}$ tentang produk kerajinan tangan Lhokseumawe. Dengan menggunakan pendekatan kuantitatif melalui penyebaran angket diperoleh hasil bahwa : persepsi generasi Y di kota Lhoksumawe terhadap kerajinan tangan produk lokal secara garis besar masih cukup dengan kualitas yang kurang dengan harga yang ditawarkan relatif mahal. Pembelian produk kerajinan tangan lokal ini hanya sebagai pemberian oleh-oleh atau cinderamata untuk memperkenalkan daerah Aceh dan masih belum menjadi budaya yang memperlihatkan kecintaan akan produk daerah.
\end{abstract}

Kata kunci: Persepsi konsumen, Produk daerah, Gen Y

\section{The perception of Y generation on local handicrafts}

\begin{abstract}
At this juncture, the growth of handicraft business in the world is quite rapidly which marked by the hard competition increasingly of handicraft products between the district of regions Aceh, therefore the handicraft entrepreneurs from Aceh must show a high competitiveness to other regional products through conduct a good marketing strategy. " $Y$ " generation is an important consumer market segment in future due to the rapid growth of this generation and is also a high-income community. Consequently, the " $Y$ " generation has attracted various research groups and scientific discipline attention. The aim of this research is to identify the perception of " $Y$ " generation regarding the Lhokseumawe handicraft product. Through the quantitative approach via questionnaire this research found that: marginally, the perception of The generation " $Y$ " at Lhokseumawe city to local handicraft products is still sufficient with low quality and the relatively expensive price. The purchasing of local handicraft products is only a gift or souvenir to introduce Aceh region and still not become a culture that shows the love of local products.
\end{abstract}

Keywords: Consumer perception, local product, Gene "Y"

\section{How to cite:}

Pasaribu, H., Rafi, C., dan Khairawati. (2017). Persepsi Generasi Y Terhadap Kerajinan Tangan Daerah. Jurnal Ilmiah Manajemen \& Bisnis, 18(2), 212-219. 


\section{PENDAHULUAN}

Perkembangan perekonomian dewasa ini mengalami kemajuan yang signifikan,dimana tiap-tiap daerah mempunyai kekayaan yang beragam,sehingga banyak masyarakat yang mulai memanfaatkan hasil alam itu,untuk membuat sesuatu yang bisa menjadi sebuah karya yang nantinya karya tersebut bisa menjadi sebuah mata pencaharian masyarakat yang mempunyai potensi dan mempunyai keahlian dalam bidang kerajinan tangan. Upaya mengembangkan produk lokal sebagai komoditas unggulan daerah merupakan salah satu strategi memberdayakan potensi lokal guna meningkatkan kemandirian suatu daerah. Produk lokal dapat dipandang sebagai salah satu identitas daerah yang menggambarkan tidak hanya aspek ekonomi tetapi juga aspek sosial budaya. Pada setiap produk-produk lokal tergambar suatu entitas kedaerahan yang terbangun puluhan tahun bahkan ratusan tahun.(opini Kebumen Express, 2017).

Provinsi Aceh merupakan provinsi yang mempunyai sumber kekayaan alam cukup besar, baik dari sektor pertanian, perkebunan, kelautan dan sektor lainnya. Konflik keamanan berkepanjangan dan gempa bumi serta tsunami tahun 2004 berdampak cukup besar terhadap perekonomian wilayah tersebut (Bank Indonesia, 2012). Dalam rangka mendorong pertumbuhan perekonomian di Aceh, pengembangan industri kerajinan tangan menjadi perhatian pemerintah daerah. Perkembangan dunia usaha produk kerajinan tangan saat ini cukup berkembang pesat ditandai dengan semakin ketatnya persaingan produk kerajinan tangan antar daerah. Industri rumah tangga di Aceh, khususnya bidang kerajinan diharapkan dapat bersaing di pasar Nasional bahkan Internasional, untuk itu pengusaha kerajinan tangan aceh harus mempunyai daya saing yang tinggi terhadap produk daerah lain dengan cara melakukan strategi pemasaran yang baik. Hal ini sesuai dengan pendapat Hoffman et al., (2002) yang mengatakan bahwa suatu jenis usaha harus bisa menunjukkan suatu konsep dan strategi pemasaran yang mendasar agar mampu menguasai pasar sasaran.

Generasi Y merupakan segmen pasar konsumen yang penting di masa depan karena statistik tahun 2009 mengungkapkan bahwa kelompok populasi ini akan mewakili kira-kira 26 sampai $30 \%$ dari total pasar konsumen global, setara dengan triliunan pasar dolar di seluruh dunia (Ang, et al., 2009). Generasi Y telah dianggap sebagai kelompok berpenghasilan tinggi yang mereka miliki (Morton, 2002). Generasi Y telah menarik perhatian beragam kelompok penelitian dalam berbagai disiplin ilmu.

Masyarakat awam khususnya generasi Y memiliki sikap atau pandangan yang berbeda-beda mengenai produk buatan lokal. Melihat trend bahwa gen $\mathrm{Y}$ masih kurang tertarik terhadap produk lokal khususnya kerajinan tangan serta mereka lebih menikmati produk-produk luar yang mereka anggap mampu mengangkat gengsi mereka, Sikap dari generasi Y tersebutlah yang akan akan mempengaruhi pembelian produk lokal. Tentu saja pemerintah daerah dan pengusaha kerajinan tangan daerah mengharapkan generasi $\mathrm{Y}$ lebih mencintai produk lokal dibandingkan dengan produk buatan daerah lain atau luar negri untuk menaikkan identitas dan citra dari daerah tersebut. Hal ini juga senada dengan kampanye pemerintah yang beberapa tahun lalu aktif mensponsori kampanye Aku Cinta Indonesia (ACI) yang mendorong penduduk Indonesia membeli atau mengkonsumsi produk dalam negri saja. Untuk mewujudkan pertumbuhan dan perkembangan kerajinan tangan daerah maka perlu mengajak kantong-kantong sosial yang belum merespon agar mau mengembangkan kerajinan tangan daerah dengan menggunakan produk daerah. Hal 
ini menjadi

kecenderungan generasi $\mathrm{Y}$ membeli produk lokal tersebut generasi Y membeli produk lokal tersebut hanya untuk cenderamata atau oleh-oleh (kerajinan tangan) kepada orang lain dan bukan untuk dipakai atau dikonsumsi sendiri sehingga menggambarkan bahwa produk tersebut hanya untuk cenderamata dan bukan sebagai alat identitas diri generasi Y sebagai orang Aceh. Dengan melihat tren yang terjadi di kalangan generasi $\mathrm{Y}$ tersebut dan persepsi generasi Y yang terbentuk ini yang dapat mempengaruhi keinginan membeli atau menggunakan produk lokal maka berdasarkan latar belakang dari permasalahan diatas peneliti ingin mengetahui persepsi generasi $\mathrm{Y}$ terhadap kerajinan tangan daerah.

\section{KAJIAN TEORI}

Persepsi merupakan salah satu dampak yang dihasilkan dari komunikasi. Persepsi menjadi penting karena perilaku manusia selalu didasarkan pada realita dari apa yang selalu di tangkap oleh indranya, pengindraan ini sangat dipengaruhi oleh kondisi pada saat terciptanya persepsi. Bagaimanapun apa yang dipersepsikan seseorang dapat cukup berbeda dari kenyataan yang objektif. Persepsi dapat didefinisikan sebagai suatu proses yang ditempuh individu untuk mengorganisasikan dan menafsirkan kesan-kesan indera mereka agar memberikan makna bagi lingkungan mereka (Robbins, 2008), sedangkan menuru Gibson, et al., (2011) mengatakan bahwa persepsi adalah proses dari seseorang dalam memahami lingkungannya yang melibatkan pengorganisasian dan penafsiran sebagai rangsangan dalam suatu pengalaman psikologis. Sedangkan menurut Kotler (2000) definisi persepsi adalah suatu proses yang mana seorang memilih, mengorganisasikan dan menginterprestasikan masukan informasi untuk memilih (membuat gambar dunia yang penuh arti). Karena persepsi itu bertautan dengan cara mendapatkan pengetahuan khusus tentang objek atau kejadian pada saat tertentu, maka persepsi terjadi kapan saja stimulus menggerakan indera, persepsi meliputi juga kognisi (pengetahuan). Jadi persepsi mencakup penafsiran objek, dengan perkataan lain persepsi mencakup penerimaan stimulus (input), pengorganisasian stimulus dan penterjemahan atau penafsiran stimulus yang telah di organisasi dengan cara yang dapat mempengaruhi perilaku dan bentuk sikap.

Setiap orang memilih berbagai macam syarat yang mempengaruhi persepsinya terhadap orang, objek dan tanda, karena faktor-faktor ini dan kemungkinan terjadinya ketidak seimbangan faktor-faktor tersebut, maka orang sering salah persepsi terhadap orang lain, kelompok atau objek (Robbins, 2008) Persepsi seseorang tidak timbul dengan sendirinya, tetapi melalui proses dan faktor-faktor yang mempengaruhi pembentukan persepsi seseorang. Hal inilah yang menyebabkan setiap orang memiliki interpretasi berbeda, walaupun apa yang dilihatnya sama. Menurut Robbins (2008) terdapat 3 faktor yang dapat mempengaruhi pembentukan persepsi seseorang, yaitu apabila seseorang melihat menginderakan sesuatu maka akan berusaha untuk memberikan interpretasi tentang apa yang diinderakan, yang dipengaruhi oleh karakteristik individual yang dimilikinya seperti pengetahuan, pengalaman pemersepsi, dll. Selanjutnya, sasaran dari persepsi dapat berupa orang, benda, ataupun peristiwa. Sifat- sifat itu biasanya berpengaruh terhadap persepsi orang yang melihatnya. Persepsi terhadap sasaran bukan merupakan sesuatu yang dilihat secara teori melainkan dalam kaitannya dengan orang lain yang terlibat. Hal tersebut yang menyebabkan seseorang cenderung mengelompokkan orang, benda, ataupun peristiwa sejenis dan memisahkannya dari kelompok yang tidak 
serupa yang didasarkan atas sikap dari pemersepsi. Di samping itu persepsi harus dilihat secara kontekstual yang berarti situasi dimana persepsi tersebut timbul, harus mendapat perhatian, situasi merupakan bagian dari proses pembentukan persepsi namun berdasarkan pada situasi yang menyebabkan persepsi itu timbul.

Secara garis besar, dapat disimpulkan mengenai faktor-faktor yang dapat mempengaruhi pembentukan persepsi yaitu, pemersepsi atau aspek dari diri sendiri yang sejatinya memiliki pilihan dalam menseleksi yang membuat terjadinya proses selektif dengan melakukan penginderaan terhadap stimuli yang dapat berupa objek atau subjek yang dapat diseleksi berdasarkan hal seperti pengetahuan dan pengalaman diri terhadap suatu hal, sasaran dari pemersepsi atau target yang berupa objek atau subjek yang di interpretasikan atau diorganisasikan sebagai hasil dari kesan yang memberikan pengaruh bagaimana cara pemersepsi bersikap atau memandang terhadap target yang dipersepsikannya, dan selanjutnya adalah situasi yang didasarkan atas situasi itu sendiri yang timbul seperti apa yang terjadi dan dapat membuat individu tertarik atau merespon terhadap objek yang dihadapkannya (Robbins, 2008).

Setiap generasi pada zamannya mempunyai ciri dan karakteristik masingmasing. Beragam kesamaan atau pun perbedaan di dalamnya layaknya dapat dijadikan sebagai gambaran umum atas bagaimana mereka berperilaku. Tentunya ini sangat penting bagi para pemasar yang sebaiknya harus mengetahui secara mendalam target pasar yang ingin ia tuju. Salah satu generasi yang paling mencolok karena terkenal dengan keragaman yang berada di dalamnya adalah Generation $Y$ atau yang biasa dikenal dengan "Echo Boomers" atau pun "Millennials" (Solomon, et al., 2009).

$$
\text { Pasar akan generasi ini }
$$
dikarakteristikan sebagai remaja yang tergolong remaja yang lebih tua dan dewasa yang muda. Secara umum, diharapkan generasi ini merupakan generasi yang paling tinggi tingkat pendidikannya, tentunya dengan tingkat pendapatan yang akan mengikuti. Kebanyakan dari "Echo Boomers" ini telah memasuki dunia perkuliahan atau pun dunia kerja (Yolanda, 2017).

Selanjutnya, literatur yang sama juga menyebutkan bahwa generasi ini tumbuh dengan kesempatan kerja penuh bagi wanita, pendapatan ganda bagi rumah tangga, menghargai keragaman suku dan budaya, keberadan komputer di sekolah dan rumah,

dan juga internet, serta ketidakpastian ekonomi (Hawkins dan Mothersbaugh, 2010). Pasar remaja merupakan pasar yang atraktif untuk dua hal. Pertama, preferensi dan selera yang dibentuk selama waktu remaja dapat mempengaruhi pembelian sepanjang waktu. Kedua, saat ini remaja mampu menghabiskan lebih dari $\$ 150$ juta per tahun untuk konsumsi personalnya (Hawkins dan Mothersbaugh, 2010). Kebanyakan dari uang yang mereka peroleh juga akan dibelanjakan pada "feel-good" products atau produk-produk yang mampu memberikan kenyamanan bagi mereka, seperti kosmetik, poster, dan makanan siap saji (Solomon, et al., 2009).

Di Indonesia sendiri, Generation $Y$ dapat dikatakan generasi yang cukup memenuhi pasar. Menurut data statistik Indonesia yang diperoleh dari SUPAS 2005 (Sensus Penduduk Antar Sensus), dapat diketahui bahwa proporsi Generation $Y$ dapat mencakup lebih dari $35 \%$ (Badan Pusat Statistik, 2005). Hal ini secara tidak langsung menunjukkan bahwa pasar generasi ini cukup besar sehingga banyak hal yang dapat dilakukan oleh pemasar untuk dapat memenuhi kebutuhan dan keinginan generasi tersebut. Selain itu, dinamika dari pasar ini juga sangat beragam. Dengan demikian, penggambaran di atas telah menunjukkan bahwa di Indonesia 
sendiri, generasi ini memang atraktif sehingga mampu menyedot perhatian pemasar agar lebih dapat mengambil setiap kesempatan dan tantangan yang muncul dari generasi ini.

Ciri utama dari generasi Y adalah technology savvy, yaitu generasi yang lahir di era teknologi dan akrab dengan teknologi baru (Rahman dan Azhar, 2011), early adopter, yaitu konsumen yang cepat mengadopsi teknologi baru, serta innovator yaitu konsumen pertama yang menggunakan informasi dan teknologi baru (Adiwaluyo, 2011).

Salah satu konsep segmentasi yang dijelaskan oleh Khasali, (1998) dalam menganalisis konsumen Indonesia adalah melalui analisis kelompok, atau pengelompokan konsumen berdasarkan generasi yahun lahirnya. Generasi $\mathrm{Y}$ telah menjadi sasaran penelitian yang sah dalam bentuk yang serupa, terutama karena kelompok populasi ini terdiri dari segmen demografis dengan daya beli yang tinggi. Ini juga merupakan segmen pasar konsumen yang sangat menguntungkan (Rugimbana, 2007). Hasil riset AC Nielsen menyimpulkan bahwa konsumen yang mengunjungi toko biasanya tidak pernah merencakan apa yang ingin dibeli sebelum berbelanja (Majalah Marketing, 2007). Hasil tersebut juga menyatakan bahwa sekitar $13 \%$ konsumen yang merencanakan pembeliannya selalu membeli item tambahan. Karena karakteristik masingmasing generasi berbeda, maka penting bagi pemasar untuk memperlakukan konsumen pada beragam kelompok usia secara berbeda (Rempel, 2009).

Gen Y memproses informasi pada level intuitif dimana semua hal bersifat visual dan kontekstual, oleh karena itu produk harus berdasarkan tampilan dan fungsinya dan bukan hanya sekedar seperti apa yang diberikan pengiklanan (Aquino, 2015). Faktor yang dapat mempengaruhi persepsi dan cara pembelian pada generasi
Y adalah keberadaan produk tersebut secara online (Honigman, 2013). Selain itu faktor lain yang dianggap penting juga adalah kualitas dari produk yang ditawarkan (Annetta \& Brian, 2015).

\section{METODE}

Penelitian ini menggunakan pendekatan kualitatif, Penelitian ini ditujukan untuk mengetahui persepsi generasi $\mathrm{Y}$ terhadap kerajinan tangan produksi daerah. Penelitian ini dilaksanakan di Kota Lhokseumawe dengan objek penelitian adalah semua lapisan masyarakat khususnya generasi $\mathrm{Y}$ yang bertempat tinggal di Kota Lhokseumawe. Populasi didalam penelitian ini adalah seluruh masyarakat generasi $\mathrm{Y}$ yang berusia antara 17 tahun hingga 37 tahun yang bertempat tinggal di kota Lhokseumawe. Prosedur untuk pengambilan sampel dalam penelitian ini dilakukan secara stratified sampling, dimana populasi dibagi terlebih dahulu menjadi kelompok-kelompok kemudian sampel diambil ditarik secara random dari setiap kelompok. Guna mendapatkan data dan informasi dalam penulisan ini, penulis mengadakan metode pengumpulan data primer. Perolehan data primer dilakukan dengan cara kuesioner yang merupakan daftar yang memuat serangkaian pertanyaan mengenai variable-variabel dalam penelitian yang diajukan kepada responden dalam bentuk tertulis. Untuk mengetahui bagaimana persepsi masyarakat terhadap kerajinan tangan produk aceh digunakan daftar pertanyaan (kuesioner), pertanyaan pertanyaan tersebut dibuat dengan menggunakan tehnik pertanyaan yang mempunyai nilai 1 sampai dengan 5 . Dengan interpretasi data hasil pengolahan berdasarkan kelompok tingkatannya dilakukan dengan menggunakan tabel distribusi. Skor terendah opsi kuisioner (tidak memuaskan) $=1$ dan skor tertinggi opsi kuisioner $($ sangat memuaskan $)=5$. 


\section{HASIL DAN PEMBAHASAN Hasil}

Dari hasil deskripsi pada penelitian ini ditemukan bahwa pengelompokan usia dapat mempengaruhi persepsi dari pembelian/pemakaian kerajinan tangan produk daerah. Dengan jumlah responden yang membeli produk daerah terbanyak adalah pada kelompok remaja usia 15-25. Selain itu faktor jenis kelamin juga dapat mempengaruhi persepsi dan pola pembelian yang berbeda, jenis kelamin konsumen yang terbanyak adalah perempuan $73 \%$. Berikutnya pada penelitian ini didapatkan hasil bahwa, konsumen yang kurang dalam memperhatikan (bentuk, corak dan harga) produk daerah adalah konsumen yang memiliki berpenghasilan tinggi. Dari data kuisioner yang didapat secara keseluruhan kerajinan tangan produk lokal sebagian besar dibeli/dikonsumsi untuk sebagai oleholeh atau cenderamata untuk memperkenalkan daerah Aceh.

\section{Pembahasan}

Temuan penelitian dapat diuraikan bahwa generasi $\mathrm{Y}$ merupakan populasi terbanyak kedua di dunia dan ini merupakan peluang dan juga tantangan, bukan hanya karena mereka kekuatan dalam membeli tetapi mereka juga dapat mempengaruhi orang tua mereka dalam mengambil keputusan pembelian. Berdasarkan hasil pengolahan data dari kuisioner bahwa menurut Gen $\mathrm{Y}$ terlihat bahwa rerata persepsi responden untuk item-item pertanyaan untuk semua faktor-faktor adalah cukup, hal ini menandakan bahwa kerajinan tangan produk lokal masih pada tahap yang biasa-biasa saja baik dalam hal produk, lokasi dan ukuran. Hal ini dikarenakan produk daerah memiliki karakteristik bentuk sederhana dan mendapatkan bahan baku dari daerah setempat. Sedangkan harapan dan latar belakang pembelian konsumen terhadap kerajinan produk lokal tinggi ini. Generasi Y sebagai generasi milenia selalu membandingkan produk daerah dengan produk luar sehingga mempengaruhi persepsi tentang atribut produk daerah tersebut dimana produk daerah terkesan inferior (rendah). Dari hasil tersebut maka gen $\mathrm{Y}$ mengharapkan suatu produk daerah yang dibeli merupakan produk yang menarik dan berkualitas. Hasil penelitian ini juga sesuai dengan penelitian Andin \& Ardiningtyas (2010) yang mengatakan bahwa ada perbedaan persepsi di antara pendapat generasi $\mathrm{X}$ dan generasi $\mathrm{Y}$ tentang kepemimpinan. Selain itu juga hasil penelitian Fatimah, et al., (2015) yang menunjukkan bahwa genearasi "Y" mempunyai persepsi yang berbeda tentang karakteristik budaya dibanding dengan generasi lain. Secara keseluruhan jenis kerajinan tangan Aceh bervariasi dengan kualitas produk yang masih cukup sedangkan harga yang ditawarkan relatif mahal. Pembelian kerajinan tangan yang banyak dikonsumsi oleh konsumen adalah produk yang bersifat sebagai pelengkap saja dengan harga yang dapat dijangkau oleh semua lapisan terutama yang berpenghasilan rendah. Produk kerajinan tangan Aceh memiliki harga yang relatif mahal, dengan tampilan yang standar

\section{SIMPULAN}

Dapat disimpulkan bahwa persepsi generasi Y kota lhokseumawe terhadap kerajinan tangan produk lokal secara garis besar masih rendah dengan pola pembelian bahwa produk daerah terutama kerajinan tangan hanya merupakan pemberian oleholeh atau cinderamata untuk memperkenalkan daerah Aceh. Para pengusaha atau pemilik toko perlu memperhatikan berbagai faktor yang mempengaruhi perilaku pelanggan, diantaranya kepekaan harus dilakukan oleh pelaku pembuatan kerajinan tangan ataupun penjual kerajinan tangan untuk menyesuaikan situasi pasar. Gen Y sebagai generasi milenia yang kuat dalam pembelian 
dan pengguna tekhnologi dalam kehidupan sehari-harinya, maka hal yang memungkinkan untuk dilakukan adalam dengan mensosialisasikan ataupun membuat promosi produk secara online, dalam penentuan harga sebaiknya para pelaku pemasar menawarkan harga yang dipersepsikan oleh konsumen sesuai dengan kualitas dan sebaiknya harga juga disesuaikan dengan kategori pemakaian, untuk para pelaku pembuatan ataupun penjualan kerajinan tangan harus memperbaiki kualitas dengan tidak melupakan nilai-nilai kedaerahan yang dapat menjadi keunggulan dan daya saing memperbaiki sistem pelayanan agar dapat mengetahu keinginan dan harapan konsumen, kesesuaian produk dikaitkan dengan pemanfaatan sebaiknya sejalan dengan budaya agar keberlanjutan akan kemudahan pengembanngan dan pelestarian kerajinan daerah tetap terjaga. Salah satu pengembangan adalah dengan melakukan inovasi terutama dalam bentuk tampilan agar lebih menarik.

\section{REFERENSI}

AC Nielsen. (2010). Hasil Riset Konsumsi Media di Indonesia. Majalah Marketing.

Adiwaluyo, E. (2011). Pasar 200 Triliun!. Majalah Marketing. April 2011.

Ang, E, Leong, H. Y., \& Kian, S. (2009). Gen Y - techinically Savvy, Available from: http://biz.thestar.com.my (diakses 23 Juli 2016).

Annetta, G., dan Muchardie, B.G. (2015). Pola Perilaku Pembelian Produk Apparel Untuk Balita Oleh Millennial Moms Dan Implikasinya Untuk Pemasar Kids Apparel. Binus Business Review, 6(1), 142-145.

Andin, A., dan Ardiningtiyas, P. (2010). Persepsi Kepemimpinan Otentik dan Work Engagement Pada Generasi X \& Y Di Indonesia, Jurnal Universitas Paramadina, 7(2), 371-388.
Aquino, J. (2012). Gen $Y$ : The Next Generation of Spenders.

Bank Indonesia. (2012). Klaster Tas Motif Bordir Lhokseumawe. Diakses $21 \mathrm{Juli}$ 2017,

from

http://www.bi.go.id/id/umkm/penelitia n/regional/aceh/Pages/tas_bordir.aspx.

Badan Pusat Statistik. (2005). Lhokseumawe Dalam Angka, Lhokseumawe: BPS.

Gibson, J. Ivancevich, J. \& Konopaske, R. (2011). Organizations: Behavior, Structure, Processes, McGraw-Hill Companies, Incorporated.

Hawkins, D.I., dan Mothersbaugh, D.L. (2010). Consumer Behavior: Building Marketing Strategy.11th edition. McGraw-Hill: Irvin.

Fatimah, H., Dharmawan, A.H., Sunarti, E., dan Affandi, M. J. (2015). Pengaruh Faktor Karakteristik Individu dan Budaya Organisasi terhadap Keterikatan Pegawai Generasi X dan Y. Jurnal Aplikasi Manajemen, 13(3), 402-409.

Hoffman., Douglas, K., John, E. G. (2002). Essentials of Services Marketing: Concepts, Strategies and Cases, Horcourt - College Publishers

Honigman, B (2013). How Millennials are Shopping: 20 Interesting Statistics \& Figures.

Khasali, R. (1998). Membidik Pasar Indonesia: Segmenting, Targeting dan Positioning. Jakarta: PT Gramedia Pustaka Utama.

Kotler, P. (2000). Manajemen Pemasaran. Ed Milenium, Jakarta: Prenhalindo.

Morton, L. (2002). Targeting Generation Y. Public Relate Q.

Rahab. Mendayasaingkan Produk Lokal. Diambil dari: http://www.kebumenekspres.com/201 6/04/ mendayasaingkan-produklokal.html. (diakses 23 Juli 2017).

Rahman, S., dan Azhar, S (2011). Xpresion of Generation Y: Perceptions of The Mobile Phone Service Industry in 
Pakistan, Asia Pacific Journal of Marketing and Logistics, 23(1), 91107.

Rempel, C (2009). Marketing to Different Generations. Security Dealer \& Integrator, 31(2), 34-36.

Robbins. R. S. (2008). Perilaku Organisasi. Jilid 1. Prentice Hall.

Rugimbana, R. (2007). Generation Y, how cultural values can be used to predict their choice of electronic financial services. Journal of Financial Services Marketing, 11(4), 301-313.

Solomon, M. R., Dann, S., Dann, S., \& Russell-Bennett, R (2007). Consumer behaviour : Buying, having, being. Frenchs Forest, NSW: Pearson Education.

Yolanda, N. (2017). Analisis faktor-faktor yang mempengaruhi perilaku belanja konsumen pada produk Apparel di Tunjungan Plaza Surabaya. Tesis. Widya Mandala Catholic University Surabaya. 